\title{
Uniform Hot Compression of Nickel-based Superalloy 720Li under Isothermal and Low Friction Conditions
}

\author{
Satoko Horikoshi ${ }^{1)^{*}}$, Akira YAnAgIdA $^{2)}$ and Jun YANAGIMOTO ${ }^{3)}$ \\ 1) School of Engineering, Tokyo Denki University, now Graduate School of Arts and Sciences, The University of \\ Tokyo \\ 2) School of Engineering, Tokyo Denki University \\ 3) School of Engineering, The University of Tokyo
}

Abstract: Isothermal compression tests at $1000^{\circ} \mathrm{C}$ and $0.1 \mathrm{~s}^{-1}$ strain rate, in which mica or glass sheets were used as a lubricant, were conducted. Isothermal condition was achieved by placing high-heat-resistant (HHR) alloys between a workpiece and ceramic tools in the induction-heating configuration to prevent heat from escaping to the ceramic tools. To perform high compression tests, it was necessary to increase the diameter of the HHR alloy, for which a new single-turn coil was designed using FEM calculation coupled with deformation-temperature electromagnetic fields. In order to obtain the correct flow stress, inverse analysis was conducted using the FEM calculation, in which temperature and strain rate fluctuations were compensated. However, the compensation was insufficient when the distribution of temperature and strain rate was large. The use of glass sheets as a lubricant considerably reduced friction and uniform deformation was achieved. Thus, flow stress obtained using the inverse analysis became extremely reliable. The flow stress of mica obtained using inverse analysis with a constant friction coefficient was different from that of glass. Introducing new friction model that the friction coefficient changed from 0.02 to 0.3 , the flow stress of mica was consistent with that of glass. Therefore, the flow stress obtained using the inverse analysis for the new configuration proposed in this study proved to be reliable.

Keywords: isothermal compression; inverse analysis; superalloy; induction heating; low friction.

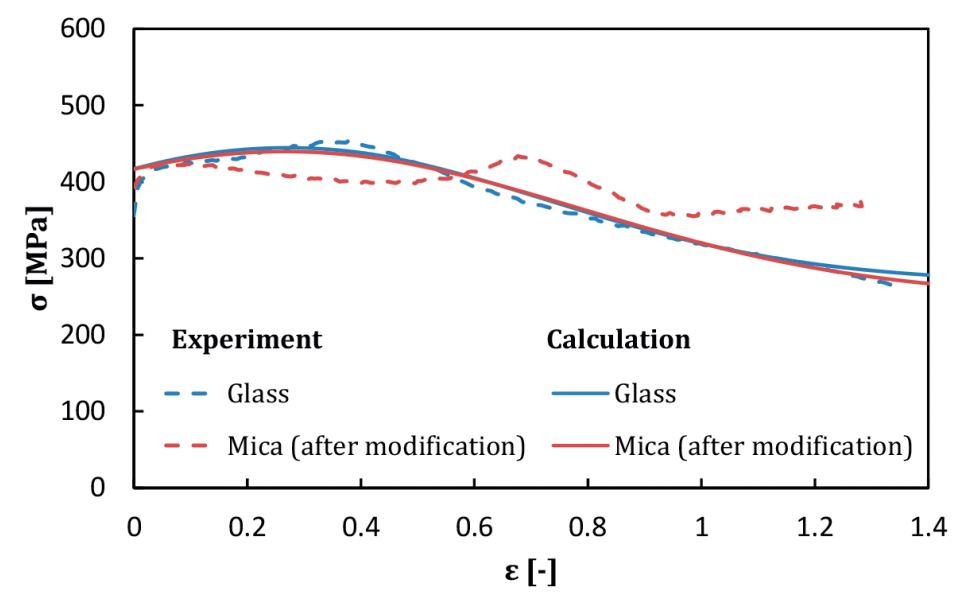

Received on Jul. 10, 2021; Accepted on Sep. 24, 2021; originally published in ISIJ Int., Vol.60, 2020, No.12, pp.2905-2916 and reprinted at the request of the ISIJ Editorial Board as it will be received the Sawamura Award in March 2022.

* Corresponding author. E-mail: sat.horikoshi@gmail.com, Address: The University of Tokyo, 3-8-1 Komaba Meguro-ku Tokyo 1538902 


\title{
温度および摩擦制御による $\mathrm{Ni}$ 基超合金（Alloy720Li）の熱間均一圧縮試験
}

\author{
堀越 理子 ${ }^{1)} *$ ・柳田 明 ${ }^{2)} \cdot$ 柳本 潤 ${ }^{3)}$
}

Uniform Hot Compression of Nickel-based Superalloy 720Li under Isothermal and Low Friction Conditions

Satoko Horikoshi, Akira Yanagida and Jun Yanagimoto

\section{1. 緒言}

析出強化鍛造用 $\mathrm{Ni}$ 基超合金は, 航空機部材やガスター ビンに広く用いられている。航空機部材における使用につ いては安全性確保のために, 材料の特性や微細構造には特 に厳格な制御が必要である。そのため, 温度・ひずみ速度 一定下で得られた熱間加工特性，すなわち精緻な流動応力 が必要となる。流動応力は, 加工時の荷重やひずみ分布な どを解析するために，多くの研究者により取得が行われて きた。Alloy720Liは高強度, 高耐食性および高い高温強度 を持つ代表的な $\mathrm{Ni}$ 基超合金であり，タービンディスクな どに用いられている ${ }^{1-3)}$ 。この合金は析出強化合金であり， $\sim 40 \%$ が $\mathrm{L} 12$ 型の規則構造を有する $\gamma^{\prime}\left(\mathrm{Ni}_{3} \mathrm{Al}, \mathrm{Ti}\right)$ 相; 二次 $\gamma^{\prime}$ と球状の三次 $\gamma^{\prime}$ が析出分散強化に寄与している ${ }^{4)}$ 。一次 $\gamma^{\prime}$ の直径は標準的には1-3 $\mu \mathrm{m}$ であるのに対し, 二次と三 次の $\gamma^{\prime}$ の直径はそれぞれ，50～500 nm と 5 30 nmである。 Alloy720Liは温度変化により析出量や固溶元素量が変化す るため, 試験中の温度制御は重要である。しかしながら, 一定温度での試験は非常に難しく, 特に小サイズの試験片 では温度変動が激しく, 試験片内の温度分布が大きくなる。 適切な温度制御を行うために, 多くの研究者が様々な加熱 システムを備えた装置を用いて, 圧縮試験を行ってきた。

1つめの例として, 油圧サーボプレスに断熱チャンバー を導入した装置が挙げられる。このシステムでは, 試験片, 工具，および周囲の䨌囲気を断熱チャンバー内で一定の温 度に維持することが可能である ${ }^{6-9)}$ 。断熱チャンバーは, 正 確な流動応力を得るのに非常に効果的であったが, 試験片 を急冷することができないため, 微細組織の変化に関する データ取得が困難である。2つめは, 直接通電加熱を用い た Gleeble熱加工シミュレータである ${ }^{10-13)}$ 。試験片と工具
の間に潤滑剤として導電性材料であるタンタルを用いる が，十分な潤滑を得ることができなかった。Gleebleによる 圧縮試験の数值解析が行われ, 摩擦による不均一変形と試 験片の長手方向に温度分布 $\left(1100^{\circ} \mathrm{C}\right.$ の試験に打いて $50^{\circ} \mathrm{C}$ の 温度分布）が発生することが報告されている ${ }^{14)}$ 。3つめは 誘導加熱を利用して温度を一定に保つ方法である。しかし ながら，七ラミック工具は加熱されないため試験片の温度 分布が発生する問題があり, 特に低ひずみ速度での試験時 における試験片の温度低下は避けることができない ${ }^{15-17) 。 ~}$ Matsui らはセラミック工具と試験片の間に $\mathrm{Ni}$ 基単結晶合 金 (CMSX-4) の加熱補助金型を用いる手法を開発し，等温 状態を達成した ${ }^{18)}$ 。しかし, 加熱補助金型のサイズ（直径） が小さかったため試験片の圧下率は $50 \%$ に制限されてい た。試験片を高圧下するために加熱補助金型のサイズを大 きくすると, 加熱補助金型が試験片よりも加熱されるため 温度が上昇し, 微細構造が变化し加熱補助金型の強度が低 下する問題が生じる。この問題を解決するためには, 加熱 コイルの最適化が必要となる。

本研究では, 誘導加熱において試験片 (Alloy720Li) とセ ラミック工具の間に高耐熱 (HHR) 合金を配置し, セラミッ ク工具への熱移動を抑制することで，等温状態を達成し た。高圧下域までの試験を実施するためには, HHR 合金の 直径を大きくする必要があり, 変形一温度一磁場解析を連 成した有限要素法 (FEM) 計算を実施し, サイズを拡大し たHHR合金に最適な 1 巻きコイルを新たに設計した。併せ て, 精緻な流動応力を得るために, 逆解析を実施した ${ }^{15,16)}$ 。 逆解析とは, FEM解析で得られた荷重と実験で得られた荷 重とが一致するまで流動応力のパラメータを修正し, 流動 応力を得る手法である。逆解析に用いた FEM解析では, 温 度とひずみ速度の変動幅が小さい場合には, 温度とひずみ

原著論文：ISIJ Int., Vol.60（2020）, No.12, pp.2905-2916, 澤村論文賞受賞論文 (2022年表彰)

2021 年7月 10 日受付 2021 年9月24日受理 (Received on Jul. 10, 2021; Accepted on Sep. 24, 2021; originally published in ISIJ Int., Vol.60, 2020, No.12, pp.2905-2916 and reprinted at the request of the ISIJ Editorial Board as it will be received the Sawamura Award in March 2022.)

1) 東京電機大学工学部 (現: 東京大学大学院総合文化研究科) (School of Engineering, Tokyo Denki University, now Graduate School of Arts and Sciences, The University of Tokyo)

2) 東京電機大学工学部 (School of Engineering, Tokyo Denki University)

3) 東京大学工学部 (School of Engineering, The University of Tokyo)

* Corresponding author. E-mail: sat.horikoshi@gmail.com, Address: The University of Tokyo, 3-8-1 Komaba Meguro-ku Tokyo $153-8902$ 
速度の依存式により補償することができるが, 変動幅が大 きい場合には十分な補償ができない。1巻きコイルを用い た等温圧縮試験により，温度とひずみ速度の変動を抑制し た。併せて圧縮試験中の潤滑状態の検討を行い, 新たな摩 擦モデルを提案し, FEM解析に導入することで, 逆解析の 精度を向上させた。

\section{2. 実験および計算方法}

\section{$2 \cdot 1$ 材料}

使用した試験片材料は, Allegheny Technologies Incから 購入したAlloy720Liの10 インチビレットである。材料の化 学組成を Table 1 に示す。 $\gamma^{\prime}$ のソルバス温度は約 $1160^{\circ} \mathrm{C}{ }^{4,19)}$ であり, 熱力学ソフトウェア (JMatPro) で計算された $\gamma^{\prime}$ ソ ルバス温度は $1154^{\circ} \mathrm{C}$ であった ${ }^{13)}$ 。ビレットには, 粒径サイ ズの分布があり, 円柱の中心位置, 中心から $\mathrm{R} / 2$ ( $\mathrm{R}$ :半径), 中心から 3R/4での試験片の平均粒径サイズはそれぞれ，

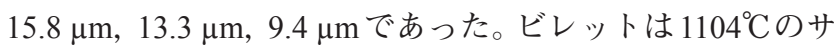
ブソルバス温度域にて 4 時間の溶体化熱処理を施した後に 空冷し, 直径 $8 \mathrm{~mm}$, 高さ $12 \mathrm{~mm} 0$ の円柱形に加工し, R/2の 位置を使用した。試験片の平均粒径は $19 \mu \mathrm{m}$ であり,これ はASTMの粒度番号で 8.5 となる。

\section{$2 \cdot 2$ 試験装置}

実験にはThermecMastorZ (富士電波工機 $\left(\right.$ 株) ${ }^{20)}$ ) を用い た。4巻きコイルを用いた従来の構成を Fig.1 (a) に示す。 Fig.1 (b) は新規に提案する構成であり, 3 ·3 節で記述する 1巻きコイルを使用し, 試験片と工具の間にHHR 合金を挿 入した。

\section{$2 \cdot 3$ 応力測定の構成}

Fig.2 (a) -2 (c) は, それぞれ, 従来の構成 (構成 A), 熱パ
ラメータを決定するための予備試験の構成 (構成 B), およ び本研究で提案された構成 (構成C) を示す。構成 $\mathrm{A}$ と構成 B には従来の 4 巻きコイルを使用し, 構成 Cでは本研究で

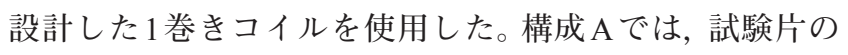
上下に $\mathrm{Si}_{3} \mathrm{~N}_{4}$ 製のセラミック工具を配置し, 潤滑性と断熱 性をあわせもつ雲母を工具と試験片の間に配置した。雲母 の断熱性が不十分であったため低温の工具への熱伝達によ り試験片の上下端の温度が低下する現象が見られた。構成 $\mathrm{B}$ と構成 Cでは試験片の温度低下を解消するために, HHR 合金としてNimowal合金（日立金属株式会社製）を用い， 試験片の上下に配置した。HHR合金の直径と高さは，それ ぞれ構成Bでは $15 \mathrm{~mm}$ と $6 \mathrm{~mm}$, 構成Cでは $17 \mathrm{~mm}$ と $5 \mathrm{~mm}$ とした。構成 $\mathrm{C}$ のHRR 合金の直径を構成 $\mathrm{B}$ の直径よりも大 きくすることにより，圧下率の高い試験が可能となった。 HHR 合金の高さは, 合金の熱容量がほぼ等しくなるよう に決定した。Nimowal は単結晶 Ni 基超合金CMSX-4等と比

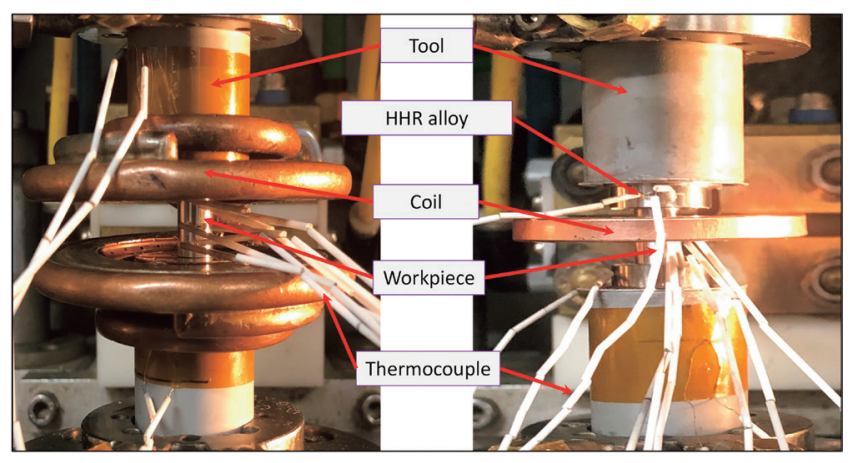

(a)

(b)

Fig. 1. Interior of the equipment: (a) conventional configuration using a four-turn coil, (b) the proposed configuration using a single-turn coil in which high-heat-resistant (HHR) alloys are introduced. (Online version in color.)

Table 1. Composition of the superalloy $720 \mathrm{Li}$ (mass \%).

\begin{tabular}{ccccccccccc}
\hline Alloy & $\mathrm{Ni}$ & $\mathrm{Cr}$ & $\mathrm{Co}$ & $\mathrm{Ti}$ & $\mathrm{Al}$ & $\mathrm{Mo}$ & $\mathrm{W}$ & $\mathrm{C}$ & $\mathrm{Zr}$ & $\mathrm{B}$ \\
\hline 720Li & Bal. & 16.13 & 14.63 & 5.01 & 2.57 & 2.99 & 1.22 & 0.018 & 0.03 & 0.014 \\
\hline
\end{tabular}

The $\gamma^{\prime}$ solvus temperature is around $1160^{\circ} \mathrm{C}$.

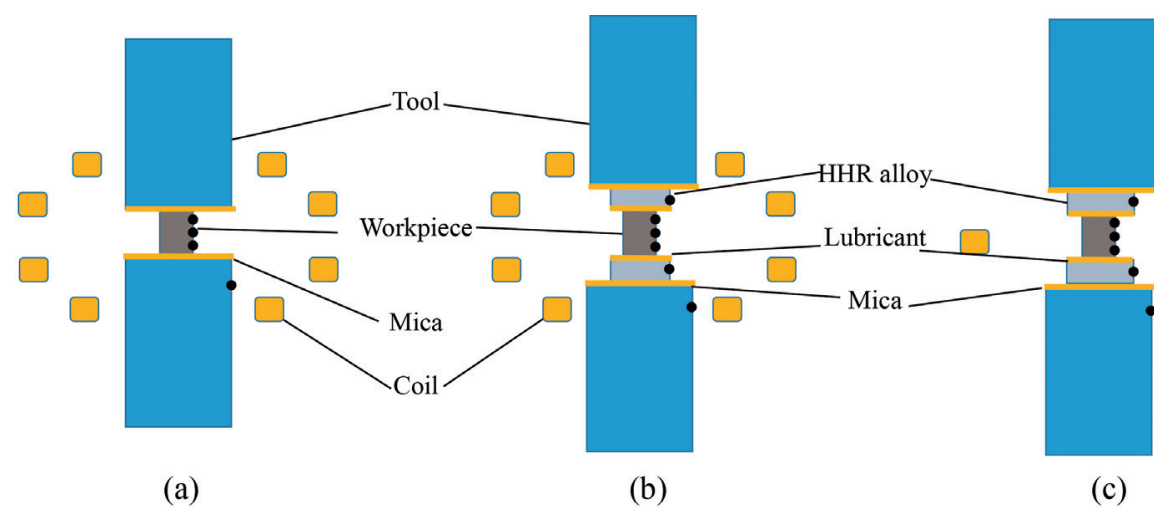

Fig. 2. Schematics of configurations: (a) conventional (config. A), (b) the preliminary tests for determining thermal parameters (config. $\mathrm{B})$, and (c) proposed (config. C). (Online version in color.) 
べて入手が容易な鋳造材料である。Nimowalのひずみ速度 $10^{-3} / \mathrm{s}$ における圧縮降伏強度は，1000 $1100^{\circ} \mathrm{C}$ の温度範囲 で710〜 580 MPである ${ }^{22)}$ 。HHR 合金は誘導加熱により試験 片とほぼ同じ温度に加熱されるため, 試験片からセラミッ ク工具への熱伝達が抑えられ, 均一温度が達成された。工 具とHHR合金の間に断熱材として雲母シートを挿入し, 試験片とHHR 合金の間に潤滑剤として雲母シートまたは ガラスシートを挿入した。ガラスシートを用いる場合に は, 溶融ガラスを保持する目的で, 試験片の上下面に中心 から $1 \mathrm{~mm}$ ピッチ, 深さ $0.2 \mathrm{~mm}$ の溝を設けた。

\section{$2 \cdot 4$ 実験方法}

円柱形試験片の底面から, $3 \mathrm{~mm}, 6 \mathrm{~mm}, 9 \mathrm{~mm}$ の位置の 試験片表面に R 型熱電対をスポット溶接し，温度を測定し た。底面から $6 \mathrm{~mm}$ の位置を制御点とし, PID制御により目 標温度に維持した。

HHR 合金の温度は，上下ともに高さ中央位置に熱電対 をスポット溶接し測定した。セラミック工具の温度は，下 側のセラミック工具の試験片側から $10 \mathrm{~mm}$ の位置にカプ トンテープで熱電対を取り付けて測定した。温度測定点を Fig.2に，黒丸で示した。実鍛造プロセスにおいては金型と 接触している被加工材の温度は低下するため, CAEに用い るためには低温域の流動応力も測定する必要がある。HHR 合金とAlloy720Liの強度バランスから, 試験温度はHHR 合 金の最高使用温度よりも低い $1000^{\circ} \mathrm{C}$ 選択した。圧縮試験 は，二相領域 $\left(\gamma-\gamma^{\prime}\right)$ 内で実施した。試験片を $10^{\circ} \mathrm{C} / \mathrm{s}$ の加熱 速度で $1000^{\circ} \mathrm{C}$ まで加熱し $400 \mathrm{~s}$ 保持し，その後 $0.1 \mathrm{~s}^{-1}$ のひ ずみ速度で，圧下率 $75 \%$ まで圧縮した。

\section{$2 \cdot 5$ 計算方法}

変形 - 温度 - 磁場を連成解析し, 誘導加熱によるジュール 熱，加工発熱打よび摩擦熱を温度解析において考慮した。 変形解析は試験片，熱解析は試験片，HHR 合金，およびセ ラミック工具, 磁場解析はコイルを含む領域全体を対象と
した。磁場解析での導電体の渦電流によるジュール熱を熱 解析と連成した。解析中, 誘導加熱のコイル電流をPIDに より制御した。構成 Cの軸対称FEM解析に用いた要素分割 を Fig.3に示す。計算時間を短縮するため, $1 / 4$ モデルで計 算を行った。Fig.3（a）とFig.3（b）は，それぞれ磁場解析に 使用した要素分割と, 熱解析・変形解析に使用した要素分 割を示している。ガラス潤滑用の溝は体積が小さいため測 定応力への影響は小さいと考え, 溝の形状はFEM モデル には含めなかった。ただし溝を設けることによる摩擦や電 熱の影響は考慮した。

逆解析手法の概要を Fig. $4^{15,16)}$ に示す。実験での圧縮試験

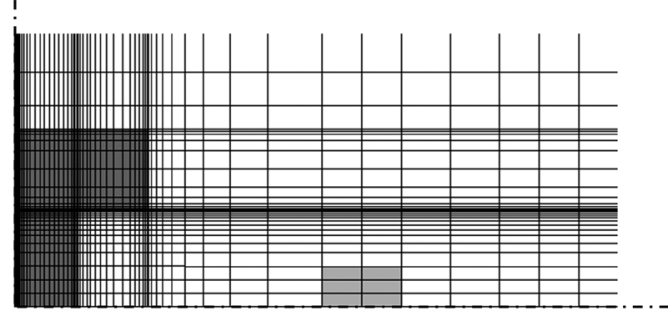

(a)

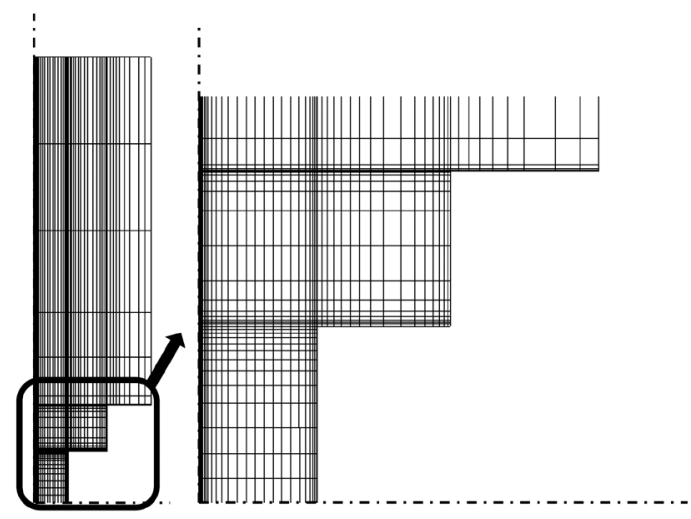

Fig. 3. Mesh used for FEM calculation of config. C: (a) for electromagnetic field analysis; (b) for temperature and deformation analysis. (Online version in color.)

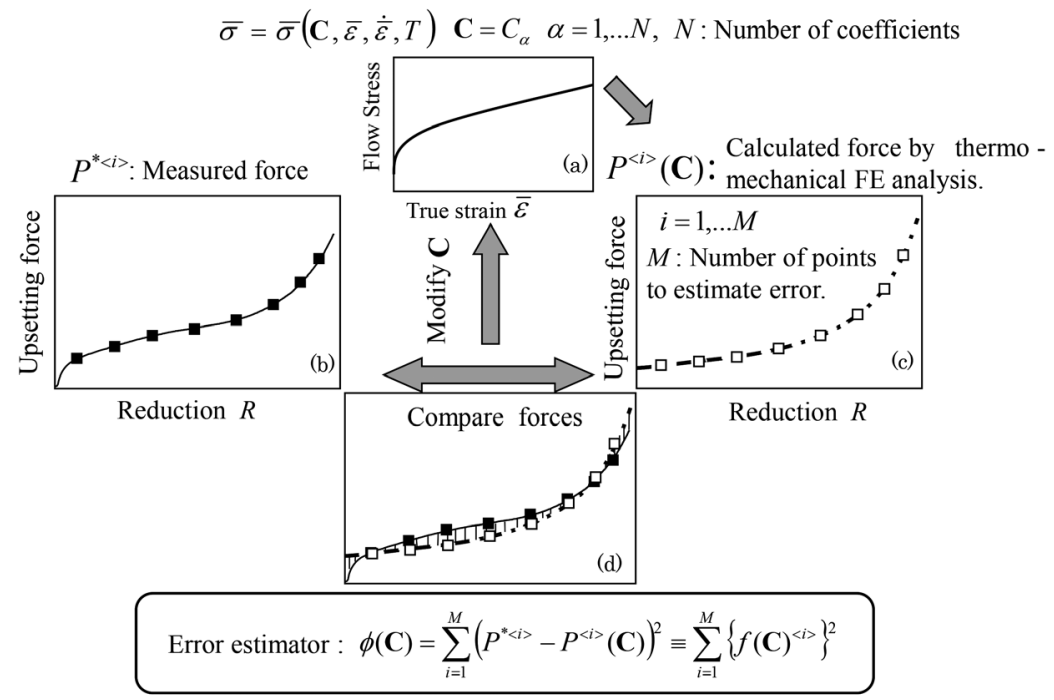

Fig. 4. Outline of inverse analysis. 
を再現するために, 変形-温度 - 磁場を連成したFEM解析 を実施した。変形解析に使用される流動応力は, 温度, ひ ずみ速度の関数として与えた。本研究で用いた Alloy $720 \mathrm{Li}$ などの高降伏点材料の流動応力を表すために, 先行研究 ${ }^{21)}$ において, 動的再結晶型流動応力式に初期ひずみ $\varepsilon_{0}$ を導入 した次式を提案した。

$$
\begin{aligned}
& \bar{\sigma}=F_{1}\left(\varepsilon_{0}+\bar{\varepsilon}\right)^{n}\left(\bar{\varepsilon} \leq \varepsilon_{c}\right) \\
& \bar{\sigma}=F_{2} \exp \left[a\left(\bar{\varepsilon}-\varepsilon_{\max }\right)^{2}\right]+F_{3}\left(\bar{\varepsilon} \geq \varepsilon_{c}\right) \\
& \bar{\sigma}^{*}=\bar{\sigma}\left(\frac{\dot{\bar{\varepsilon}}}{\dot{\overline{\varepsilon_{0}}}}\right)^{m} \exp \left[A\left(\frac{1}{T}-\frac{1}{T_{0}}\right)\right]
\end{aligned}
$$

ここで, $\bar{\sigma}$ は相当応力, $\bar{\varepsilon}$ は相当ひずみ, $F_{1}, F_{2}, F_{3}, \varepsilon_{0}, n$, $\varepsilon_{c}, \mathrm{a}$, および $\varepsilon_{\max }$ は材料パラメータである。 $\varepsilon_{c}$ における関数 の 1 次微分, 2 次微分の連続性を考慮することにより, 独立 な材料パラメータは, $F_{1}, \varepsilon_{0}, n, \varepsilon_{c}$ および $\varepsilon_{\max }$ の 5 パラメー タとなる。この 5 パラメータに初期值として適切な值を代 入し FEM解析を実施する。式 (1)〜 (3) を用いたFEM解析 により得られた荷重を Fig.4 (c) に示す。一方, 実験によっ て得られた荷重はFig.4（b) である。実験と計算でそれぞれ 得られた荷重を比較し (Fig.4 (d)), 実験值と計算值の差が 小さくなるように流動応力のパラメータを最適化する。計 算值と実験值の差が小さくなり, 最適な流動応力関数が得 られるまで, 最適化の計算を繰り返す。FEM解析では試験 片内部の温度, ひずみ, ひずみ速度等の分布を計算する。 FEM解析において, 温度とひずみ速度の分布を補正する ために式 $(3)^{15,16)}$ を使用した。ここで, $A$ と $m$ はそれぞれ温 度とひずみ速度の依存指数である。今回の計算では, $m=$ $0.1, A=8300 \mathrm{~K}^{-1}$ を使用した。これらの值は, 温度とひず み速度を変化させて実施したいくつかの試験におけるひず み 0.05 での応力值を回帰することにより算出した。この式 を用いFEM解析中に流動応力の補正を行うが, 温度 $T_{0}$, ひ ずみ速度就近傍に打いてのみ適切な補正が可能である。

\section{3. 結果}

\section{$3 \cdot 1$ 熱パラメータの決定}

熱パラメータを得るために, 既存の 4 巻きコイルを使用 して予備実験を実施した。HHR合金を使用した構成A よび構成 Bの実験を行った。両方の構成で使用した 4 巻き コイルの写真を Fig.1 (a) に示す。試験中の温度測定結果を Fig.5に破線で示す。Fig.5の (a)，(b)，(c) は，それぞれ構 成 A, 潤滑剂として雲母シートを使用した構成 B（構成 B. Mica), 潤滑剂としてガラスシートを使用した構成 B (構成 B. Glass）の温度を示している。Fig.5 (a) は, 構成Aの制御 点の温度は $1000^{\circ} \mathrm{C}$ でるが, 制御点の上下 $3 \mathrm{~mm}$ の位置で は温度が $20^{\circ} \mathrm{C}$ 以上低下していることを示している。対照的
に，HHR合金を使用した構成 $\mathrm{B}$ は，雲母，ガラスを使用し た場合共に, 制御点からの温度差は $10^{\circ} \mathrm{C}$ 未満となっている。

材料の熱パラメータは文献值を使用した。ただし，異な る材料間の熱伝達は実験的に決定する必要があり，計算で は材料間に中間層を設け，実験温度を再現できるように その厚さを最適化することによって, 熱伝達を再現した。 Table 2 に熱パラメータを示す。比熱, 電気伝導率, 熱伝導 率のパラメータは温度依存性があるため, 計算では温度依

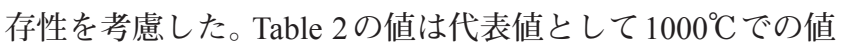
を揭載した。

得られた熱パラメータを使用して得られた計算結果を
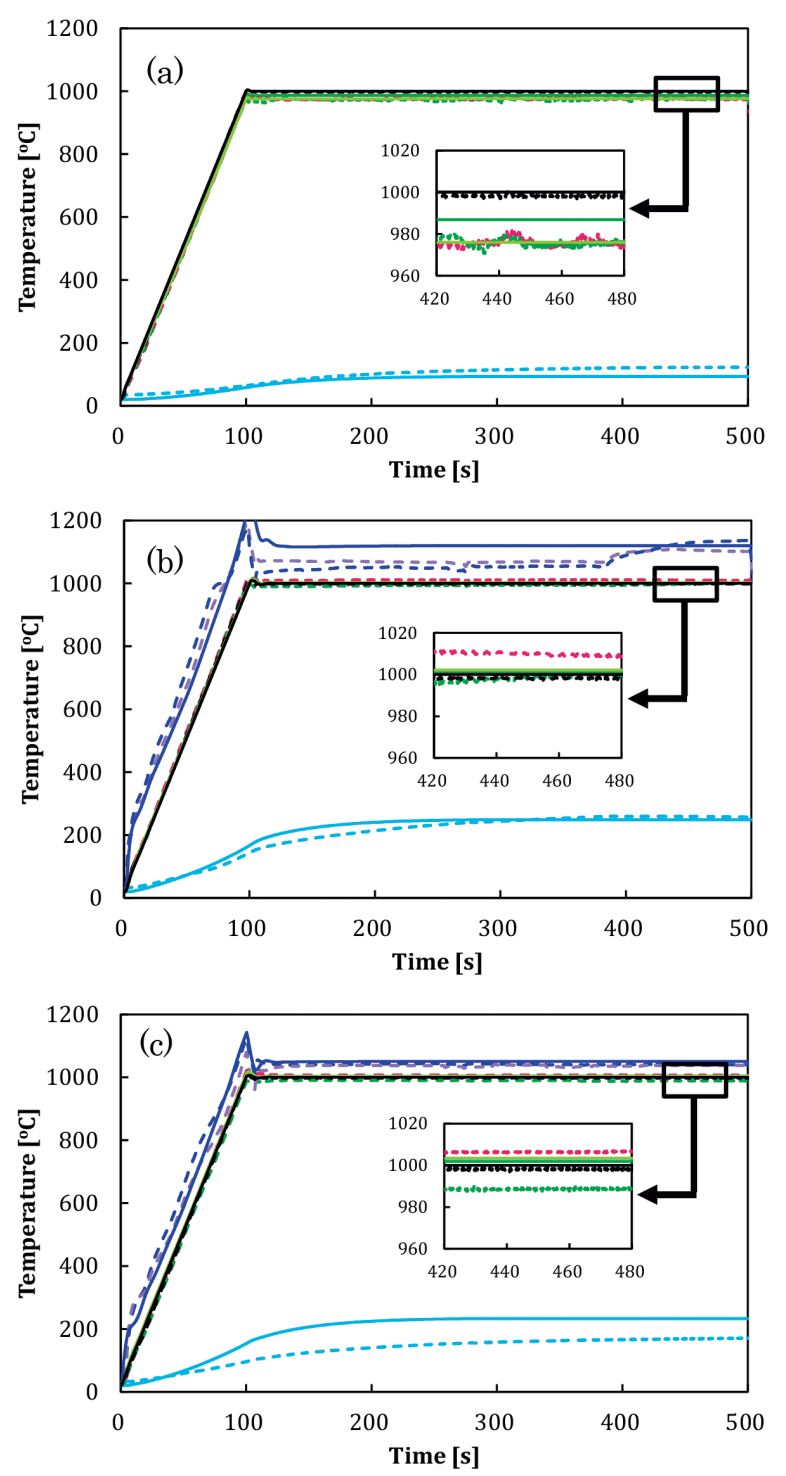

Calculation

- Control point $\quad-3 \mathrm{~mm}$ above $\quad-4 \mathrm{~mm}$ above - HHR alloy $\quad-$ Tool

Experiment

- - Control point

$--\cdot$ HHR alloy upper

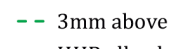

$--\cdot 3 \mathrm{~mm}$ below

- - HHR alloy lower _ - - Tool

Fig. 5. Temperature determined through experiments (dashed lines) and through numerical calculations (solid lines): (a) config. A, (b) config. B with mica, and (c) config. B with glass. All configurations used a four-turn coil. 
Fig.5に実線で示す。Fig.5から計算結果と実験結果とがよ く一致していることが分かる。

\section{$3 \cdot 2$ コイル配置の最適設計}

4 巻きコイル, 直径 $15 \mathrm{~mm}$, 高さ $6 \mathrm{~mm}$ の HHR 合金を使 用して圧下率 $75 \%$ の圧縮試験を実施した。この時試験片が 工具の中心に正しくに配置されていない場合, HHR 合金 からはみ出す結果となり，75\%の圧縮試験を実施するには HHR 合金の直径を大きくする必要があることが判明した。 HHR 合金の直径が大きくなると，4巻きコイルではHHR 合 金の温度が上がりすぎ，許容温度を超えてしまう可能性が ある。そこで，数值計算により最適なコイル配置を設計し た。潤滑剤として雲母を使用した場合について，いくつか のコイル配置について計算を実施した。Fig.6に各コイル配 置の断面図および，制御点を $1000^{\circ} \mathrm{C}$ 加熱し $400 \mathrm{~s}$ 保持後 の温度分布を示す。4巻きコイルではHHR 合金の温度が約 $1200^{\circ} \mathrm{C}$ まで上昇する結果となった。Fig.6に示すように 1 巻 きコイルを使用した場合にHHR 合金の温度上昇が最も抑

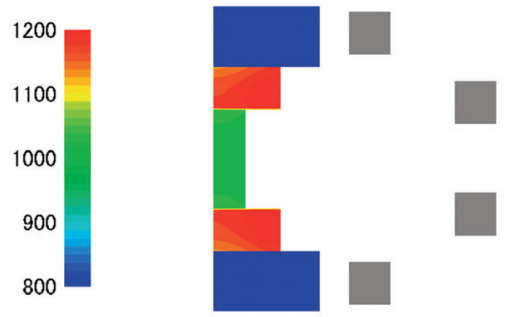

(a)

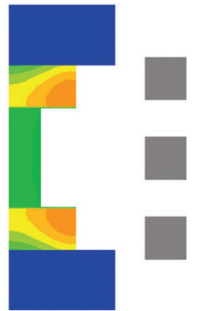

(b)
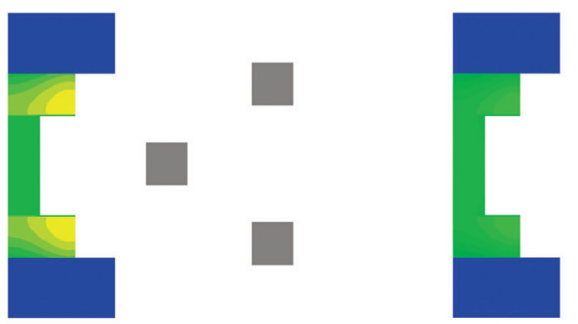

(d)

Fig. 6. Cross-sectional views of coil arrangements and contours showing the temperature distribution after the arrangements were heated to $1000^{\circ} \mathrm{C}$ and held for $400 \mathrm{~s}$.

Table 2. Thermal parameters used in the calculations.

\begin{tabular}{|c|c|c|c|c|c|c|}
\hline Layer & Workpiece & HHR alloy & Tool & Mica & Glass & Intermediate layer \\
\hline Material & Udimet720Li & Nimowal & $\mathrm{Si}_{3} \mathrm{~N}_{4}$ & Mica* & Borosilicate glass** & - \\
\hline $\begin{array}{l}\text { Density } \\
\rho / \mathrm{J} \mathrm{kg} \mathrm{m}^{-3}\end{array}$ & 7934 & 8760 & 3200 & 2100 & 2600 & 4300 \\
\hline $\begin{array}{l}\text { Specific heat capacity } \\
\qquad / \mathrm{J} \mathrm{kg}^{-1} \mathrm{~K}^{-1}\end{array}$ & $888^{* * *}$ & $565^{* * *}$ & 710 & 880 & 880 & 790 \\
\hline $\begin{array}{l}\text { Electric conductivity } \\
\sigma / \mathrm{MS} \mathrm{m}^{-1}\end{array}$ & $0.649 * * *$ & $0.595^{* * *}$ & - & - & - & - \\
\hline $\begin{array}{l}\text { Thermal conductivity } \\
\qquad \kappa / \mathrm{W} \mathrm{m}^{-2} \mathrm{~K}^{-1}\end{array}$ & $35.910 * * *$ & $22.4 * * *$ & 29.3 & 1.22 & 1.24 & $\begin{array}{l}0.034 \text { (before compression) } \\
0.102 \text { (during compression) }\end{array}$ \\
\hline $\begin{array}{l}\text { Heat transfer coefficient } \\
\qquad \mathrm{H} / \mathrm{W} \mathrm{m}^{-1} \mathrm{~K}^{-1}\end{array}$ & 11 & 11 & 11 & 11 & 11 & 11 \\
\hline $\begin{array}{l}\text { Thickness } \\
\mathrm{d} / \mu \mathrm{m}\end{array}$ & - & - & - & 200 & 30 & $\begin{array}{c}15 \text { (b/w mica-metal) } \\
3 \text { (b/w glass-metal) }\end{array}$ \\
\hline Radiation coefficient $\mathrm{E}$ & & & & & .78 & \\
\hline
\end{tabular}

* Natural mica : Muscovite $\mathrm{KAl}_{2}\left(\mathrm{AlSi}_{3} \mathrm{O}_{10}\right)(\mathrm{OH})_{2}$

** $\Phi 15$ cover glass (MATSUNAMI GLASS IND., LTD.)

$* * *$ Value at $1000{ }^{\circ} \mathrm{C}$
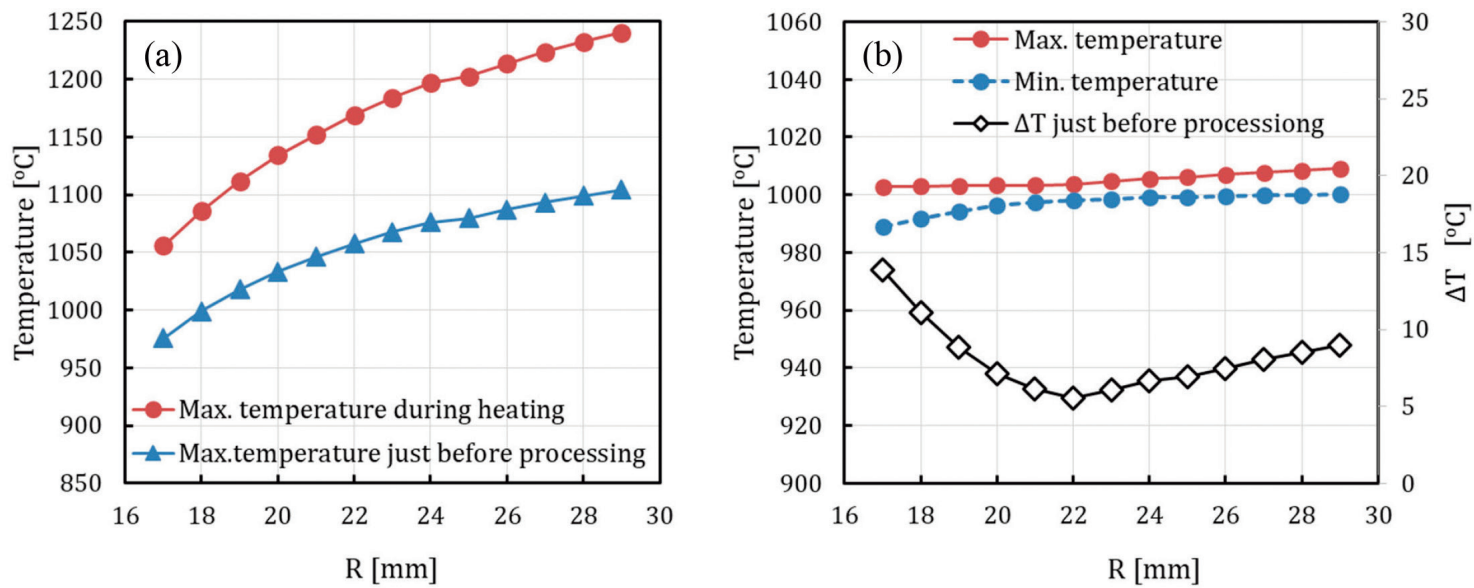

Fig. 7. Calculation results obtained by varying the winding radius of the single-turn coil: (a) maximum temperature at the surface of the mid-height of the HHR alloys during heating and just before processing and (b) maximum and minimum temperatures of the workpiece and their difference $(\Delta T)$ just before processing. 
えられる結果となった。

数值シミュレーションを実施し, 直径 $17 \mathrm{~mm}$, 高さ $5 \mathrm{~mm}$ のHHR 合金を使用した時の, 1 巻きコイルの最適な巻き半 径を決定した。コイルの断面を $5 \mathrm{~mm} \times 5 \mathrm{~mm}$ の正方形形状 とし,コイルの巻き半径を変化させて計算を実施した。

1巻きコイルの巻き半径を変化させた場合の計算結果を Fig.7に示す。Fig.7 (a) は, コイルの巻き半径を $17 \mathrm{~mm}$ から $29 \mathrm{~mm}$ まで変化させたときのHHR 合金の表層高さ中央点 での最高温度を示している。加熱中 (オーバーシュート時) の HHR 合金の最高温度，および $400 \mathrm{~s}$ 保持後 (加工直前)の 温度についてFig.7 (a) に示す。試験片の加工直前の最高温 度と最低温度、およびそれらの温度差 $\Delta \mathrm{T}$ を Fig.7 (b) に示す。

コイル半径Rが大きくなるにつれて, HHR 合金の温度も 上昇する傾向となった。試験片の温度分布の解析により, 巻き半径 $22 \mathrm{~mm}$ の時に, $\Delta \mathrm{T}$ が最小となった。

\section{$3 \cdot 31$ 巻きコイルを用いた試験}

$3 \cdot 2$ 節で述べたように 1 巻きコイルを設計し, 巻き半径 $22 \mathrm{~mm}$ のコイルを作製し, 圧縮試験を行った。

$3 \cdot 3 \cdot 1$ 測定温度と解析温度の比較

Fig.8に1巻きコイルによる加熱時の温度変化を示す。実 験結果を破線で解析結果を実線で示す。Fig.8 (a) および 8 (b) は，それぞれ構成C. Mica打よび構成 C. Glassの結果を 示している。これらの図は, 解析結果と実験結果がほぼ等 しいことを示している。1巻きコイルを使用して得られた 実験結果は, 温度の非対称性が 4巻きコイルを使用して得 られたものと比較して減少することを示している。4巻き コイルの場合, HHR 合金とコイルとが非常に近い位置にあ るため, HHR 合金の中心軸の配置が温度に強く影響する が, 1巻きコイルの場合, 軸ずれによる温度への影響は比 較的小さい結果となった。

温度の上下非対称性をなくすためには, コイルの上下中 心位置を試験片の高さの中心に配置する必要があるが, 4 巻きコイルの場合コイルの巻き数が多くコイル構造が複雑 であるため, 最適な位置に配置するのが困難であった。一 方, 1 巻きコイルの場合は, 構造が比較的単純であるため 位置決めが容易となった。

圧縮時の温度変化を Fig.9に示す。左に計算結果, 右に実 験結果を示す。実駼結果は圧縮開始後に加工発熱により制 御点の温度が上昇し, コイル電流が低下することを示して いる。電流が低下すると, コイルに近いHHR合金が最も影 響を受け，HHR合金の温度が急激に低下する。実験系全体 ではコイル電流の増減と発熱のバランスにより, 制御点の 温度が変動する。FEM解析中での目標温度を $1000^{\circ} \mathrm{C}$ とし てPID制御を実施したが，実験での温度変動を再現するこ とはできなかった。そこで, 実験中に測定した制御点の温 度を目標温度として計算することにした。

数值解析結果については, 試験片内部の中心点温度も併 記した。試験片内部の温度を実験的に測定することは困難
であったため, 解析結果のみをプロットしている（マゼン タの線)。

構成 Aでは実験結果と解析結果が定性的に一致したが, 実験での制御点から上下 $3 \mathrm{~mm}$ の温度降下は解析結果より も大きかった。また解析による試験片内部温度は加工時間 の経過とともに低下し最終的に $150^{\circ} \mathrm{C}$ 低下した。

構成C. Glass は, 実験結果と計算結果は同様の値を示し ている。測定温度を目標温度として計算したため制御点温 度が一致しているのは当然であるが, HHR 合金の温度上昇 と下降のタイミングについても実験と計算結果で合致して いる。実験結果では試験片の制御点から上下 $3 \mathrm{~mm}$ の位置 で測定值にばらつきがあり，若干の非刘称性が見られた。 特に, 圧縮開始から7秒経過した時点でHHR合金の上下に 温度差が生じ, 試験片の制御点より $3 \mathrm{~mm}$ 上の点の温度が 上昇し, 逆に制御点から $3 \mathrm{~mm}$ 下の点で温度が低下する結 果となった。しかし, 試験片の制御点の上下 $3 \mathrm{~mm}$ の測定 温度の平均值は, 解析結果とほぼ合致した結果となった。

構成 C. Micaの解析結果は, 実験值を制御点の目標温度 として解析したため制御点の温度は実験值と一致してい
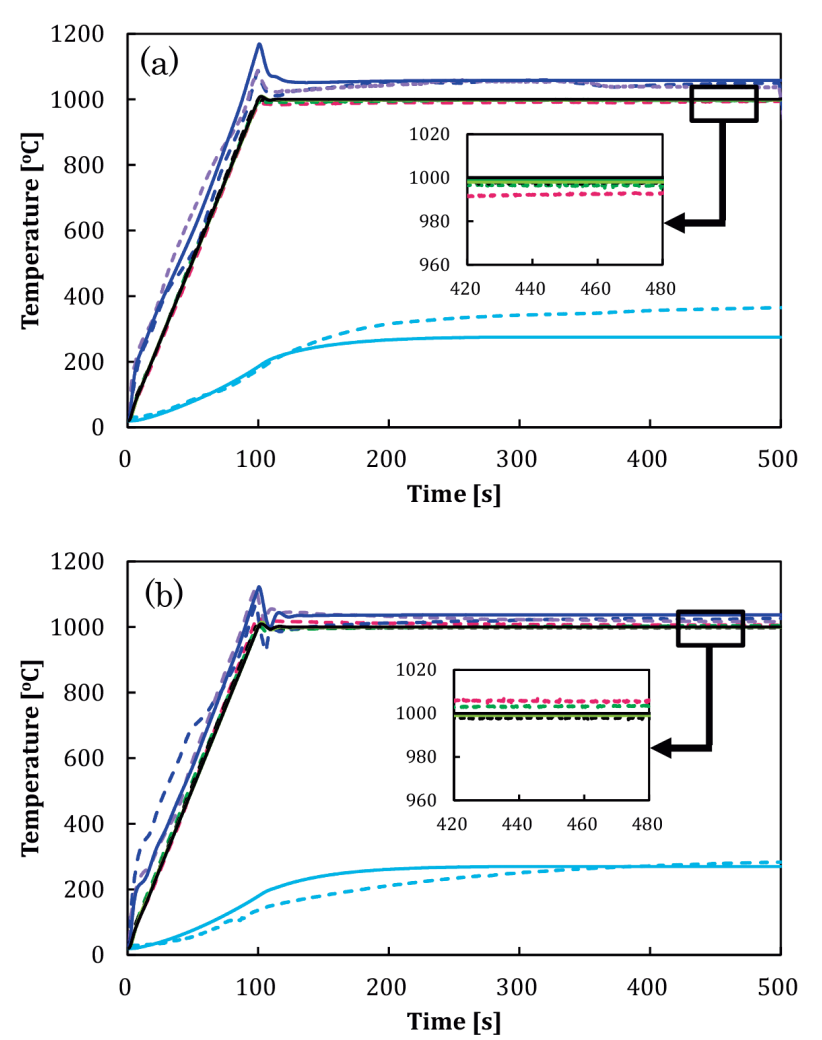

Calculation

- Control point $\quad-3 \mathrm{~mm}$ above $\quad-4 \mathrm{~mm}$ above $\quad$ - HHR alloy $\quad$ - Tool

Experiment

$$
\begin{array}{lll}
--\cdot \text { Control point } & --3 \mathrm{~mm} \text { above } & --3 \mathrm{~mm} \text { below } \\
--\cdot \text { HHR alloy upper } & -- \text { HHR alloy lower } & --\cdot \text { Tool }
\end{array}
$$

Fig. 8. Temperature values obtained through experiments (dashed lines) and numerical calculations (solid lines): (a) config. C with mica and (b) config. $\mathrm{C}$ with glass. These configurations used a new single-turn coil. 
るが，HHR 合金の温度は実験結果とは大きく異なる結果と なった。実験では圧縮開始直後は電流がゼロになったが, 計算では電流が増加し，それに伴いHHR合金の温度がわ ずかに上昇した。その結果，HHR合金の温度において開始 $3 \mathrm{~s}$ 後に小さなピークが現れた。構成 C. Micaにおいて実験 ではマイカの断熱性のため試験片の加工発熱が制御点の温 度を上昇させたと考えられる。しかし，解析ではマイカの 断熱性が不十分で, 加工発熱だけでは制御点の温度上昇を 再現できなかったと考えられる。解析においては制御点の 実測温度を目標温度として解析したため，電流を増加させ て制御点の温度を調整し，そのためHHR合金温度の小さ
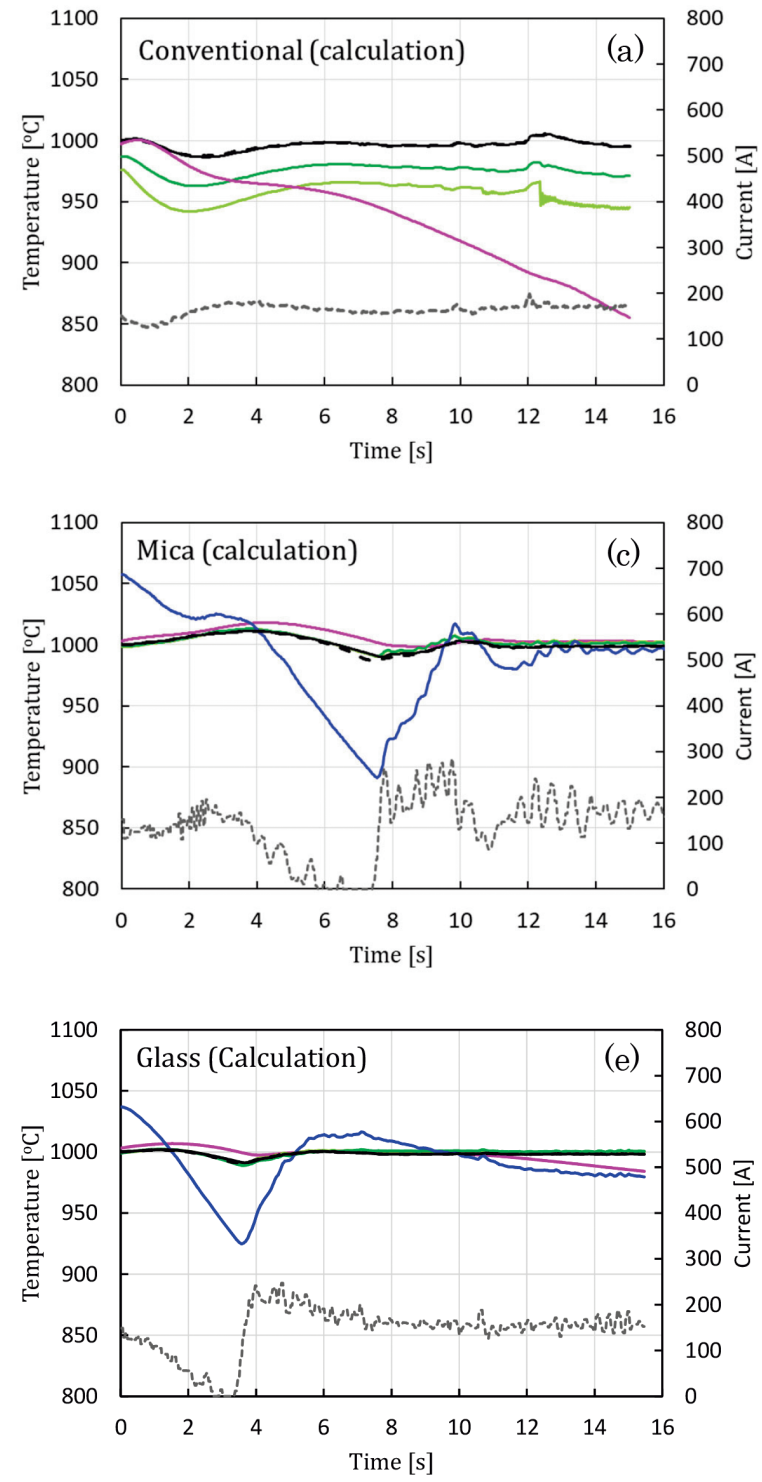

Calculation

- - Target - Control point $-3 \mathrm{~mm}$ above $\quad 4 \mathrm{~mm}$ above

- Center

$$
\begin{array}{ll}
\text { - Control point } & -3 \mathrm{~mm} \text { above } \\
\text { - HHR alloy } \quad---- \text { - Current }
\end{array}
$$

なピークが観察されたと考えられる。実際の雲母の断熱性 は計算で使用された值よりも高い可能性がある。雲母の断 熱性が高いと仮定して計算すると, HHR 合金の小さなピー クは消えたものの, HHR 合金の温度が上昇し計算温度が 実験值と一致しない結果となった。解析では, 雲母の熱物 性は雲母内のすべての場所において等しいと仮定してい るが，実際は1枚の雲母内でも場所によって異なっている 可能性がある。例えばHHR合金と試験片の間の雲母にお いて試験片と接触していない箇所では，実際は雲母がHHR 合金の表面に完全に密着していない可能性があり，そのた め断熱が不十分となり実験值と計算值の差が生じている可
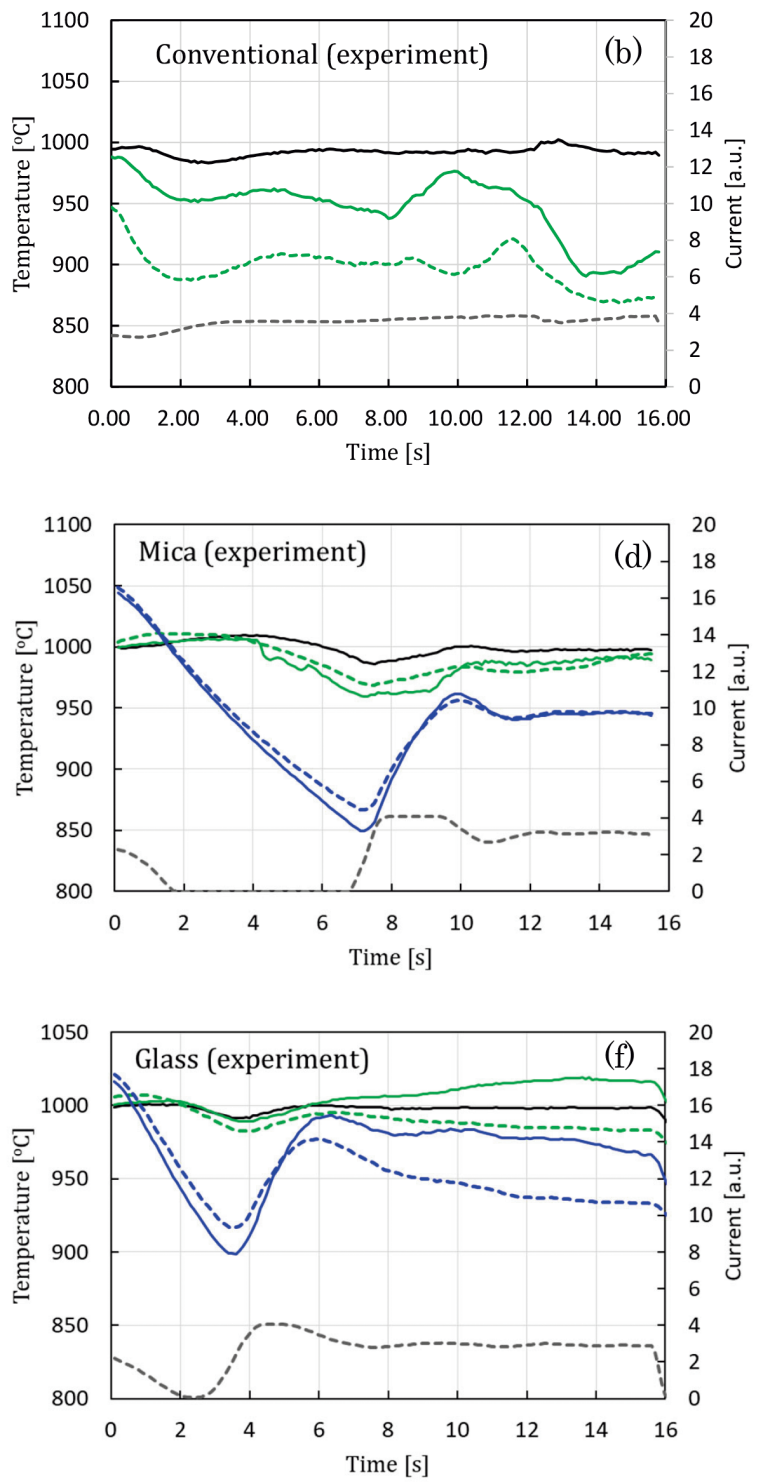

Experiment

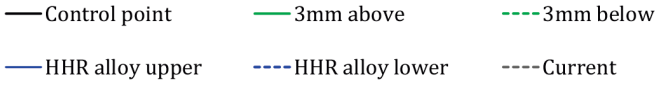

Fig. 9. Numerical calculation and experimental results of temperature during compression (calculation results are on the left; experimental results are on the right): (a), (b) config. A; (c), (d) config. C with mica, and (e), (f) config. C with glass. Proposed configurations used a new single-turn coil. 
能性がある。

また，試験片とHHR 合金の間の雲母，およびHHR合金 と工具の間の雲母は, 同じ熱物性を有すると仮定して計算 したが, 実際には配置場所により物性值が異なっている可 能性が考えられる。HHR合金と工具との間の雲母は, 圧縮 試験後に色などの変化はなかったが, HHR 合金と試験片の 間の雲母の色は高熱のため銀色に変色していた。したがっ て, 雲母の熱物性は, 実際には配置場所によって異なる場 合があると考えられる。

構成 C. Micaで得られた実験結果は, 試験片の制御点の 上下 $3 \mathrm{~mm}$ の位置で温度が低下することを示している。し かし，これらの結果は計算では再現できなかった。前述の ように, HHR 合金と雲母の間の等価熱伝達係数は, 計算で は一定値として設定したが, 実際は雲母の端部がHHR合 金と完全に接触していなかったため, 断熱が不十分であっ た可能性がある。解析ではコイル側に近いHHR 合金の角 部で最高温度となったが, 実際の実験では熱が放出される ためにそこまで高温に達していない可能性がある。さら に, 熱電対の構造上高周波磁場中での正確な測定值の取得 は難しいことが知られて打り, 制御点の上下 $3 \mathrm{~mm}$ のコイ ルとの相対的な位置関係が変化しているため, 測定精度に 問題があった可能性も考えられる。

\section{$3 \cdot 3 \cdot 2$ 圧縮試験結果}

圧縮試験後の試験片の上面図と側面図を Fig.10に示す。 左から, 構成 A, 構成 C. Mica, 構成C. Glassであり, それぞ れについて圧下率は $68 \%, 76 \%, 73 \%$ であった。すべての構 成において $75 \%$ の圧下率を目標としたが, 構成Aでは $68 \%$ の圧下率となった。この原因としては, 試験片端部の温度 が低下したため荷重が増加し装置のたわみが増加し試験片 の圧下が不十分となったためであると考えられる。

構成 $\mathrm{A}$ の側面写真では樽型の変形が観察される。構成 C.
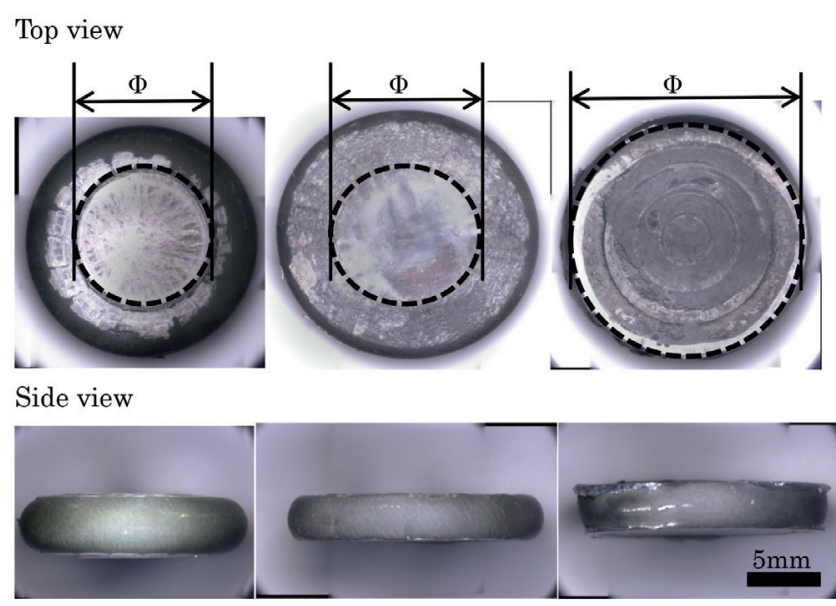

(b)

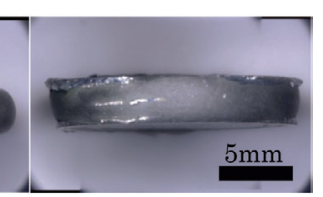

(a)

(c)

Fig. 10. Top and side views of the workpiece after compression: (a) config. A (68\% reduction), (b) config. $\mathrm{C}$ with mica (76\% reduction), and (c) config. $\mathrm{C}$ with glass $(73 \%$ reduction).
Micaにおいても, 側面の曲率が大きく樽型の形状が観察 される。これとは対照的に, 構成 C. Glass は側面の曲率は 小さく樽型の形状を示していない。上面図において $\Phi$ の違 いを示している。 $\Phi$ は変形前の円柱の底面であった円が変 形後に広がった直径を示している。構成 C. Glass は円柱の 上下面に彫られた溝が全面に広がっている。構成C. Mica の場合, 円柱の接触面はそれほど広がらず $\Phi$ は約 $11 \mathrm{~mm}$ あった。数值解析により $\Phi$ の值から摩擦係数を推定した。 その結果, 雲母を使用した構成 Aおよび構成 C. Micaでは $\mu=0.18$, ガラスシートを使用した構成 C. Glassでは $\mu=$ 0.02 の值が得られた。

荷重の測定結果をFig.11（a）に破線で示す。今回提案し た構成 Cの荷重は従来構成 $\mathrm{A}$ よりも低い結果となった。構 成 C. Mica と構成 C. Glass は, 同程度の荷重を示した。ただ し, 構成C. Micaは圧下率が大きな領域では荷重が増加す る結果となった。压縮時の荷重は温度変動に対応して変動 したと考えられる。圧縮開始直後は加工発熱とHHR 合金 からの伝熱により制御点の温度が上昇し, PID制御により コイル電流が減少するため, 光の後温度が低下する。制御 点の温度が目標温度を下回ると PID制御により電流が増加 し, 温度が上昇する。荷重は温度上昇により低下し, 温度 低下により上昇したといえる。実験で得られた温度と荷重 データを比較することにより, 温度と荷重の変化のタイミ
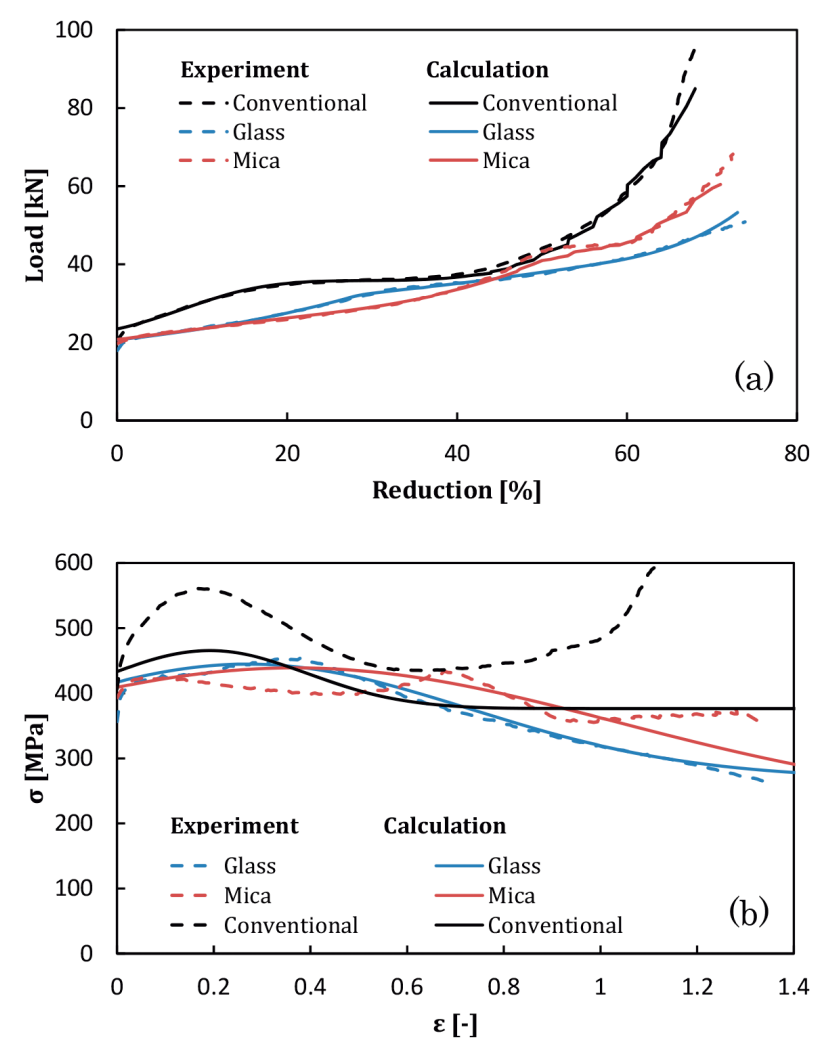

Fig. 11. Experimental results (dashed lines) and numerical calculation results (solid lines): (a) the load results and (b) flow stress obtained by experiments and calculations (inverse analysis). 
ングが一致していることを確認した。

$3 \cdot 3 \cdot 3$ 逆解析結果

流動応力の測定結果をFig.11（b）に示す。破線は実験荷 重から単純に求めた応力であり, 試験片が円柱形状を維持 したまま変形すると仮定して計算した值である。実線は逆 解析により得られた流動応力值を示している。解析には3. $3 \cdot 2$ 節において算出した摩擦係数を用いた。Table 3 の上部 3 行に逆解析によって得られた独立パラメータを示した。 3 つの構成において試験片はすべて同じ材料を用いているた め, 逆解析により得られた流動応力は, FEM解析が実験を 正しく反映したならば，一致するはずである。

構成 $\mathrm{A}$ では, 温度分布が大きく, 試験片の端部で大幅に 温度が低下することが観察され，解析における流動応力の 補正は不十分であったと考えられる。構成 C. Mica と構成 C. Glass は両者とも温度分布は小さかったにも係わらず異 なる結果となった。構成 C. Glassではひずみが増加するに つれて応力が低下したが, 構成 C. Mica は構成 C. Glass に比 べて加工軟化が小さい結果となった。

\section{4. 考察}

Fig.12に60\%圧縮した試験片の外観を示す。構成 C. Mica と構成 C. Glass は，どちらも樽型形状を示していない。76\% 圧縮時 (Fig.10) の構成 C. Micaの写真では, 変形前の円柱 の底面の直径 $\Phi$ が, 構成 C. Glass $\Phi$ と比較して拡大して いなかった。60\%圧縮時には，構成 C. Mica と構成 C. Glass の形状はほぼ同じであった。構成C. Micaでは, 元の円柱の 接触境界が接触面全体の $1 \mathrm{~mm}$ 内側にあった。 圧縮中の荷重の変化を同時に表現するために, 摩擦係数に ついて検討を行った。圧縮初期には雲母とガラスの摩擦係 数は同程度であるが圧縮中に急激に増加すると推測した。 圧縮中に摩擦係数が増加することが報告されており ${ }^{23-26)}$, いくつかの研究では摩擦係数が指数関数で近似されてい る ${ }^{24-26)}$ 。しかし, 圧縮途中から摩擦係数が急激に変化する ような場合に指数関数を適用すると, より高次の指数関数 が必要となりひずみが大きくなるにつれ摩擦係数は無限大 となる。観察された現象を場合分けせずに単一の式で表す ために式 (4) を提案した。式(4)を用いて逆解析を実施した。

$$
\mu=\frac{\mu_{f i n}-\mu_{i n i}}{2} \operatorname{erf}\left[\frac{x-x_{\text {mid }}}{t}\right]+\frac{\mu_{f i n}+\mu_{i n i}}{2}
$$

ここで, $x[\%]$ は圧下率, $x_{\text {mid }}[\%]$ は摩擦係数が変化する 圧下率の中間值, $\mu_{i n i}$ は初期摩擦係数, $\mu_{f i n}$ は最終摩擦係数, $t$ は傾きに関する值である。Fig.13に雲母の圧下率に対する 想定摩擦係数を示す。 $\mu_{i n i}=0.02, \mu_{f i n}=0.3, x_{\text {mid }}[\%]=47$, $t=5$ を用いた。

逆解析によって得られた流動応力の結果を Fig.14 (b) に 示す。構成 C. Micaの流動応力は, 構成 C. Glassの流動応力
とほぼ一致した。修正摩擦モデルを実装した逆解析により 得られた独立パラメータを Table 3 の最下段に示す。逆解析 後の荷重を Fig.14 (a) に実線で示す。摩擦係数として式 (4)

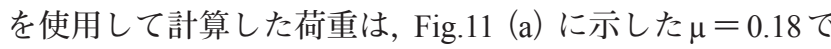
一定值であると仮定して解析された荷重よりも実験荷重 (破線) に近くなり両者はほぼ一致した。構成C. Micaにお いて圧縮中に摩擦係数が変化すると仮定し, 逆解析によっ

Table 3. Independent parameters obtained by inverse analysis

\begin{tabular}{cccccc}
\hline & $F_{1}$ & $\varepsilon_{o}$ & $n$ & $\varepsilon_{c}$ & $\varepsilon_{\max }$ \\
\hline conventional & 546.1 & 0.3196 & 0.2030 & 0.0303 & 0.191 \\
\hline glass & 165.7 & 2.159 & 1.209 & -0.202 & 0.270 \\
\hline mica* $^{*}$ & 166.5 & 2.306 & 1.089 & -0.308 & 0.368 \\
\hline mica** $^{*}$ & 165.7 & 2.205 & 1.183 & -0.272 & 0.265 \\
\hline
\end{tabular}

* before improvement of friction coefficient

** after improvement of friction coefficient

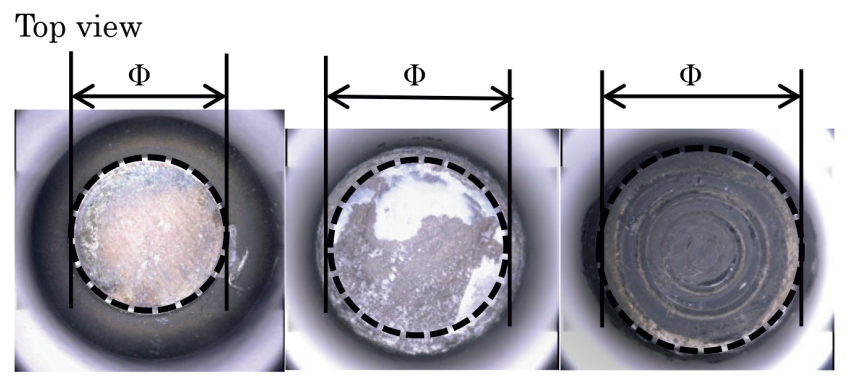

Side view

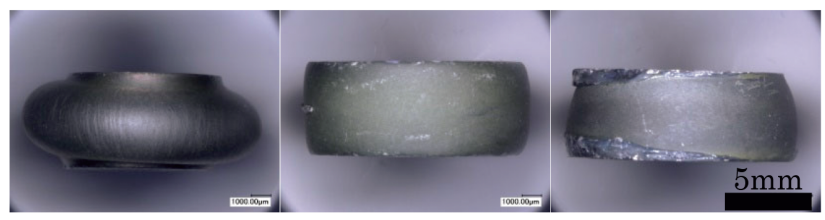

(a)

(b)

(c)

Fig. 12. Top and side views of the workpiece after $60 \%$ compression: (a) config. A, (b) config. $\mathrm{C}$ with mica, and (c) config. $\mathrm{C}$ with glass. (Online version in color.)

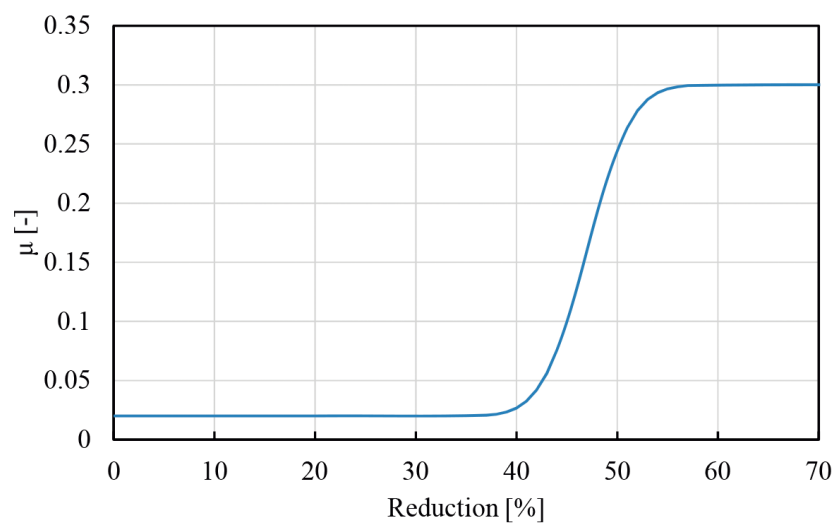

Fig. 13. Assumed friction coefficient for config. C with mica with respect to reduction. The friction coefficient changed from 0.02 to 0.3 . (Online version in color.) 

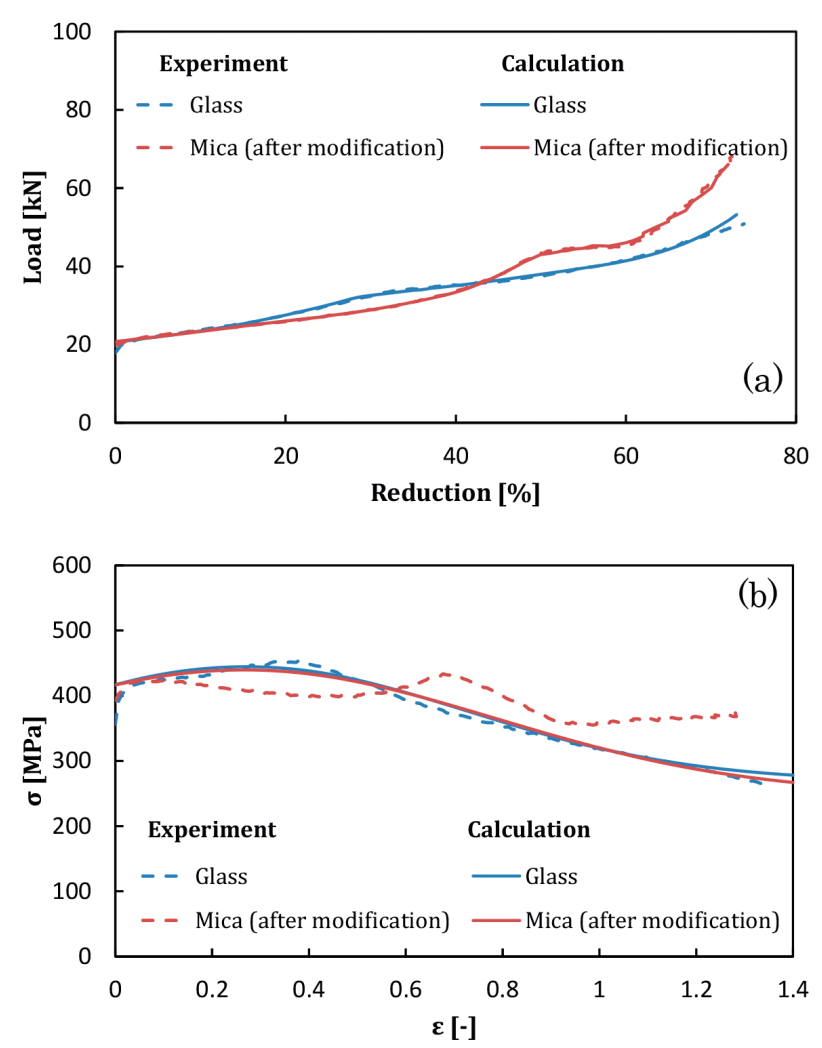

Fig. 14. Inverse analysis results for the proposed configuration after introducing a friction coefficient modification for config. C with mica: results of the (a) load and (b) flow stress obtained by experiments and numerical calculations (inverse analysis).
て得られた流動応力は，より真值を表現していると言える。 $68 \%$ 圧縮時の温度分布の解析結果をFig.15に示す。 Fig.15 (a)〜 (c) は, 同じ温度範囲のコンター図を示してお り，今回提案した構成では従来構成と比較して温度分布幅 が非常に狭いことが分かる。Fig.15（d）と15（e）は，詳細 な検討のために提案構成 (構成 $\mathrm{C}$ ) の温度範囲を $17^{\circ} \mathrm{C}$ に設 定した。Fig.9 (c)，(e)に計算での試験片内部温度をマゼン タで示したが，構成C. Micaの内部温度は圧縮後に低下し ていなかったが，構成C. Glassではわずかに低下していた。 Fig.15 (e) から，構成C. Glass の内部温度がわずかに低下し たことが分かる。

Fig.16に68\%圧縮時の相当ひずみ分布を示す。従来構成 Aではひずみ分布は大きいことが分かる。構成C. Micaで 得られた結果は, 急激な摩擦係数の上昇によりせん断变形 が打こり局所的にひずみが増加している領域がある。構成 C. Glass では試験片は均一に変形しておりひずみ分布は小 さい。

解析により求めた相当ひずみ速度を Fig. 17 に示す。相当 ひずみ速度は体積平均值で表し, 高低線で標準偏差の範囲 を示した。図中の黒線は単軸圧縮試験で求めた実験值を示 す。Fig.17 (a) の構成Aに示すように, 実験での軸方向ひず 及速度は圧下率が $50 \%$ を超えると減少した。圧下率が $30 \%$ を超えると相当ひずみ速度の計算值が単軸実験での值より

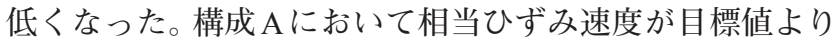
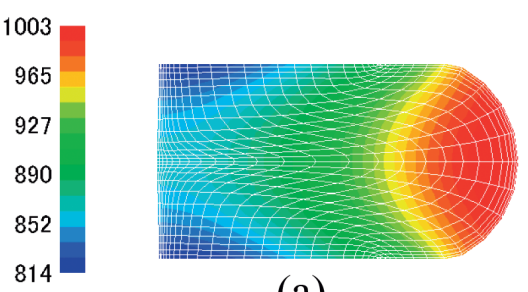

(a)

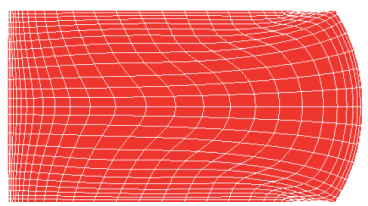

(b)

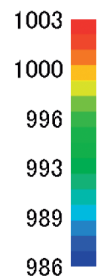

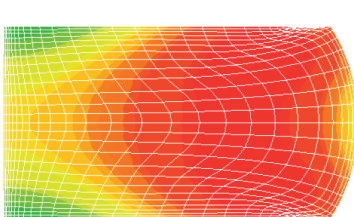

(d)

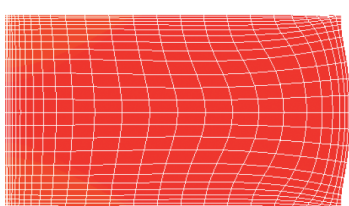

(c)

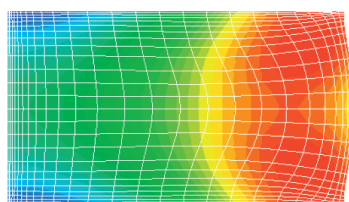

(e)

Fig. 15. Temperature distribution at $68 \%$ compression: (a) config. A; (b), (d) config. C with mica; (c), (e) config. C with glass; (a)-(c) temperature range $814^{\circ} \mathrm{C}-1003^{\circ} \mathrm{C}$ and (d), (e) temperature range $986^{\circ} \mathrm{C}-1003^{\circ} \mathrm{C}$.
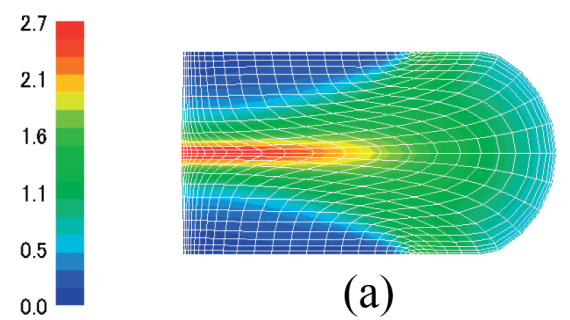

(a)

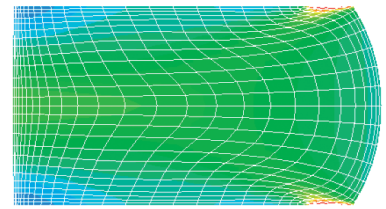

(b)

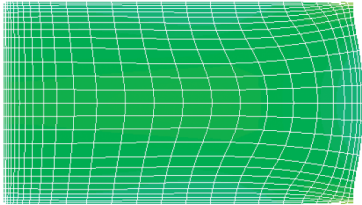

(c)

Fig. 16. Strain distribution at $68 \%$ compression: (a) config. A, (b) config. $\mathrm{C}$ with mica, and (c) config. $\mathrm{C}$ with glass. 

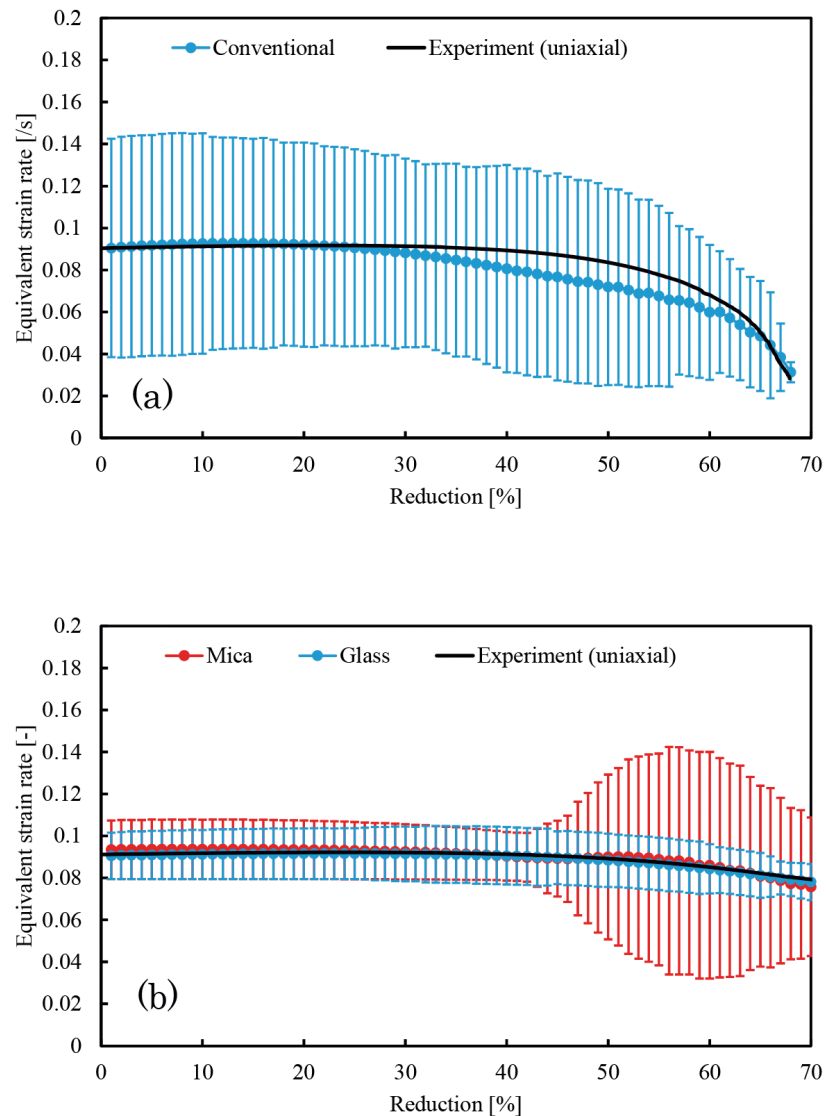

Fig. 17. Equivalent strain rate obtained by calculation with reduction: (a) config. A and (b) config. $\mathrm{C}$ with mica (red) and config. $\mathrm{C}$ with glass (blue). Black lines indicate the strain rate during the uniaxial compression test in the experiments.

大きく低下していることがわかった。Fig.17 (b) の構成C. Micaの場合, 変形時の摩擦係数の増加が反映されている。 圧下率が $50 \%$ を超えると相当ひずみ速度の平均值がわず かに増加し，その分布は大幅に増加した。圧縮の初期段階 では, 試験片は低摩擦で均一に変形するが, 急激に摩擦が 大きくなり接触面が拡大できずに，圧下率が $45 \%$ を超える とフォールディングが発生した。この結果は, Fig.16 (b) に おいて高ひずみ領域が発生した現象を示している。Fig.17 (b) の構成 C. Glass では相当ひずみ速度はほぼ一定であり, 試験片全体のひずみ速度は単軸圧縮試験と一致しており, 均一に変形したことがわかる。

\section{5. 結論}

本研究では，試験片の上下に高耐熱合金を配置すること により, セラミック工具への熱の移動を防ぎ, 均一な温度 で実験を行うことに成功した。高圧縮の試験を実現するた めに新しいコイル形状を設計し, そのコイルを使用して圧 縮試験を実施した。設計には, 圧縮試験を再現できる変形 一温度一磁場連成FEM解析を用いた。

以下の結果が得られた。
（1）ガラスシートを潤滑剤として使用することにより，摩 擦が大幅に減少し, 均一な変形が可能となった。従っ て逆解析により得られた流動応力は, 非常に信頼積が 高いものとなった。

（2）雲母を使用した提案構成の場合, 圧縮試験後の試験片 の形状から, 変形中に摩擦係数が急激に增加すること が予測された。実験により得られた試験片の形状と, 計算により得られた試験片の形状が一致するように, 摩擦係数を推測し摩擦係数が 0.02 から 0.3 に変化する モデルを提案した。提案モデルを用いて逆解析を実施 した結果, 雲母を用いた提案構成の流動応力はガラス シートを用いた流動応力とほぼ一致した。

(3) 逆解析により得られた従来構成の流動応力は, 今回提 案された構成での結果と異なるが, 概算值としてはそ れほど大きな差はない。従って, 従来の構成を使用し ても，逆解析により打打よその流動応力を得ることが 可能である。

\section{謝辞}

この研究の一部は総合科学技術・イノベーション会議の $\operatorname{SIP}$ (戦略的イノベーション促進プログラム)「革新的プロ セスを用いた航空機用耐熱材料創製技術開発」(管理法人： JST）の支援を受け実施したものである。実験材料はプロ ジェクトの共通材料として, SIPからの提供を受けた。ま た, 実験を担当した東京電機大学卒業生の相田友輝氏, 曽 我龍熙氏に感謝の意を表す。

\section{文献}

1) R.C. Reed: The Superalloys - Fundamentals and Applications, Cambridge University Press, Cambridge, (2006).

2 ) D.Furrer and H.Fecht: JOM, 51(1999) 14. http://doi.org/10.1007/ s11837-999-0005-y

3 ) H.Monajati, A.K.Taheri, M.Jahazi and S.Yue: Metall. Mater. Trans. A, 36(2005), 895. https://doi.org/10.1007/s11661-005-0284-z

4 ) M.P.Jackson and R.C.Reed: Mater. Sci. Eng. A, 259(1999), 85. https://doi.org/10.1016/S0921-5093(98)00867-3

5 ) M.Preuss, P.J.Withers, J.W.L.Pang and G.J.Baxter: Metall. Mater. Trans. A, 33(2002), 3215. https://doi.org/10.1007/s11661-002-0307-y

6 ) R.Kopp, M.Tschirnich, M.Wolske and J.Klower: J. Eng. Gas Turbines Power., 124(2002), 931. https://doi.org/10.1115/1.1494096

7 ) P.Zhang, C.Hu, C.-g.Ding, Q.Zhu and H.-y.Qin: Mater. Des., 65(2015) 575. http://doi.org/10.1016/j.matdes.2014.09.062

8 ) J.Chen, J.Dong, M.Zhang and Z.Yao: Mater. Sci. Eng. A, 673(2016), 122. http://doi.org/10.1016/j.msea.2016.07.068

9 ) K.Sahithya, I.Balasundar, P.Pant T.Raghu, H.K.Nandi, V.Singh, P.Ghosal and M.Ramakrishna: Mater. Sci. Eng. A, 754(2019), 521. https://doi.org/10.1016/j.msea.2019.03.083

10) B.C.Xie, Y.Q.Ning and C.Zhou: Procedia Eng., 207(2017), 1093. https://doi.org/10.1016/j.proeng.2017.10.1136

11) Y.C.Lin, K.-K.Li, H.-B.Li, J.Chen, X.-M.Chen and D.-X.Wen: Mater. Des., 74(2015), 108. http://doi.org/10.1016/j.matdes.2015.03.001

12) K.-K.Li, M.-S.Chen, Y.C.Lin and W.-Q.Yuan: Mater. Des., 111(2016), 344. http://doi.org/10.1016/j.matdes.2016.09.007

13) F.Liu, J.Chen, J.Dong, M.Zhang and Z.Yao: Mater. Sci. Eng. A, 
651(2016), 102. http://doi.org/10.1016/j.msea.2015.10.099

14) C.J.Bennett, S.B.Leen, E.J.Williams, P.H.Shipway and T.H.Hyde: Comput. Mater. Sci., 50(2010),125. https://doi.org/10.1016/j.commatsci. 2010.07.016

15) A.Yanagida, J.Liu and J.Yanagimoto: Mater. Trans., 44(2003), 2303. https://doi.org/10.2320/matertrans.44.2303

16) A.Yangida and J.Yanagimoto: ISIJ Int., 45(2005), 858. https://doi. org/10.2355/isijinternational.45.858

17) T.Matsui: Mater. Trans., 54(2013), 512. https://doi.org/10.2320/ matertrans.M2012202

18) T.Matsui, M.Ito and H.Takizawa: J. Jpn. Soc. Technol. Plast., 59(2018), 78 (in Japanese). https://doi.org/10.9773/sosei.59.78

19) F.E.Sczerzenie and G.E.Maurer: Superalloys 1984, Metallurgical Society of AIME, Warrendale, PA, (1984), 573. https://doi.org/10. 7449/1984/Superalloys_1984_573_580

20) A.Yanagida, M.Ikeda, H.Komine and J.Yanagimoto: ISIJ Int.,
52(2012), 574. https://doi.org/10.2355/isijinternational.52.574

21) S.Horikoshi, N.Endo, Y.Yajima, A.Yanagida and J.Yanagimoto: Proc. 67th Japanese Joint Conf. for the Technology of Plasticity, Japan Society for Technology of Plasticity, Tokyo, (2016), 119 (in Japanese)

22) T.Ohno, R.Watanabe and T.Nonomura: Trans. Iron Steel Inst. Jpn., 27(1987), 34. https://doi.org/10.2355/isijinternational1966.27.34

23) E.S.Puchi-Cabrera, J.-D.Guerin, J.G.La Barbera-Sora, J.C.AlvarezHostos, P.Moreau, M.Dubar and L.Dubar: Exp. Mech., 60(2020), 445. https://doi.org/10.1007/s11340-019-00492-5

24) Y.P.Li, E.Onodera, H.Matsumoto and A.Chiba: Metall. Mater Trans. A, 40(2009), 982. https://doi.org/10.1007/s11661-009-9783-7

25) Y.Li, E.Onodera and A.Chiba: Mater. Trans., 51(2010), 1210. https:// doi.org/10.2320/matertrans.M2010056

26) F.Jiang, J.Tang, D.Fu, J.Huang and H.Zhang: J. Mater. Eng Perform., 27(2018), 3083. https://doi.org/10.1007/s11665-018-3375-x 